\title{
Analysis Of Customer Satisfaction On The Application Of The Covid-19 Protocol At The Inter-City Bus Terminal
}

\author{
Andri Irfan Rifai*, Dimar Fazadi Rafianda, Muhammad Isradi, Amar Mufhidin \\ Faculty of Engineering, Mercu Buana University, Jakarta, Indonesia \\ *Corresponding author E-mail: andrirfan@yahoo.com
}

Manuscript received 1 Jan 2021; revised 10 Jan 2021; accepted 15 Jan 2021. Date of publication 20 Jan 2021

\begin{abstract}
The rise of the Covid-19 outbreak in Indonesia, especially Bekasi City, it is very strong influencing the existing regulations at the Bekasi city main terminal the author wants to research customer satisfaction with the facilities and implementation of the Covid-19 protocol at terminal bus in Bekasi City. This study aims to describe the perception of satisfaction customers using a questionnaire against health protocols in terminal facilities in the terminal main bus Bekasi. This method is carried out by direct survey to the location research in order to obtain data on existing facilities. Then also with distributed questionnaires to 90 respondent. The population taken in the study these are customers at the Bekasi City Main Terminal. The data processed in this study uses Microsoft Excel and SPSS versions 24 and 16 with method used by Importance Performance Analysis (IPA). It was found that the performance level facilities and customer satisfaction that must be considered in A Quadrant. The main priority is for smoking prohibition, drainage, special access pedestrians / passengers with special needs, luggage storage, charging station, and the facilities for a nursing room.
\end{abstract}

Keywords: Importance Performance Analysis (IPA), Facilities, Customer Satisfaction, Public Transport.

\section{Introduction}

Customer satisfaction is the perceived benefit of a product in accordance with the customer expects (Amir, 2013). Besides that, there is also an impact of customer satisfaction on the health protocols enforced by the government for public facilities due to the pandemic Covid-19 in Indonesia and even the world. Corona virus disease or Covid-19 is a large family of viruses that cause infection upper respiratory tract mild to moderate (Rizal Fadli, 2020). Bekasi City is one of the cities affected by the corona virus itself. Bekasi City is a city within the Greater Jakarta area and is the fourth major city in Indonesia. Bekasi City is affected by the economic growth experienced by the Indonesian capital, namely population growth. In line with the increasing population in Bekasi City and as a city that has a very strategic position and role in national development, the arrangement of the infrastructure for the Bekasi City area becomes important so that all development activities can be carried out optimally and in a structured manner so that there is a strong relationship between development activities. One of the developments that the government has been attention during the Covid-19 pandemic in the service sector. One example of a service sector that has a vital role in supporting various daily activities is the transportation service sector (Salam et al., 2013).

The right method to use in this problem is Importance Performance Analysis (IPA). In this method, the measurement level of conformity to determine how much passengers / consumers are satisfied with the existing facilities at Bekasi City Main Terminal, and how the facility providers understand what passengers want about the facilities that they are provide. The level of conformity is a result of comparison between the perception and the expected score. This level will determine the priority order of facilities services provided by Bekasi City Main Terminal starting from very appropriate order. 

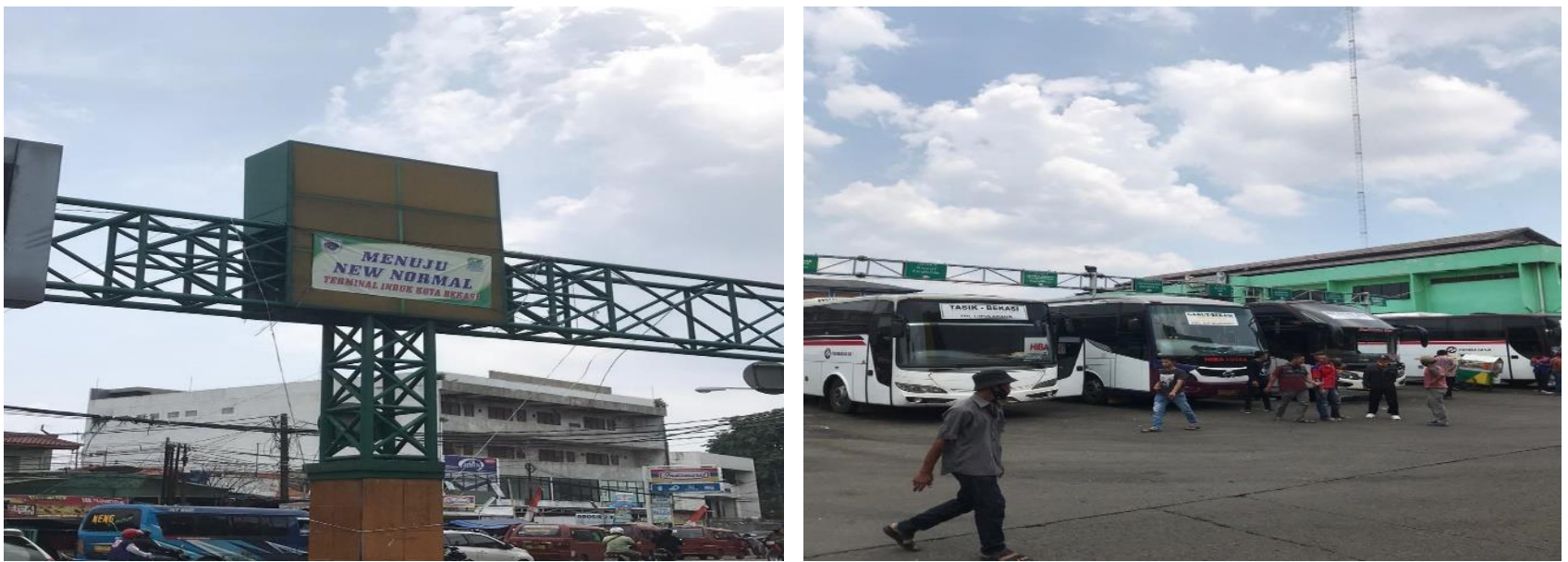

Fig 1. Bekasi City Main Terminal

\section{Literature Review}

Public transport terminals are places between items or people from one place to another by using public transportation services that are controlled by humans. Public transport terminals also an important object in every city because they really help facilitate the people in that city. Terminal is defined as the point where passengers, an items come and leave the transportation system. Terminals can also be a place to change modes or routes (Ody Wahyu, et al, 2015).

In public transportation, negative incidents, such as vehicle delays, lack of information, missing information or rude employees have the highest impact on customer satisfaction. Examples of these negative incidents include the vehicle delays, lack of vehicle information, misinformation, or rude employees according to Friman, 2004 in (Celik et al., 2013).

According to Friman et al. 2004 in (Celik et al., 2013), in contrast to being service customers who are focused on positive feelings, avoiding dissatisfaction tends to be the destination of passengers while using public transport services according to Miller, 1995 in (Celik et al., 2013) presents an outline London Underground's methods aim to improve customer service and ensure customer satisfaction. There is some knowledge of how customers perceive public transport.

In literature, aspects such as reliability, frequency, travel time, fare levels, comfort and cleanliness, network stop-out range and safety issues are all recognized as important factors in customer evaluation of public transit service quality. In addition, Friman and Gärling, 2001 in (Friman \& Fellesson, 2009) underlines the importance of clear and simple transportation information. Public transport in Ghana particularly intercity bus transport has seen a good increase in bus preference as the sector continues to offer passengers more options in terms of the type of vehicle used (Amponsah \& Adams, 2016).

Some of earliest studies in this field were carried out by Allen and DiCesare (1976) in (Agarwal, 2008) which assessed the quality of service for public transportation industry contained two categories: users and non-users. This technique allows critical aspects of the service provided to be identified and customer satisfaction enhanced (Cuomo 2000) in (Eboli \& Mazzulla, 2007). Customers who have had a pleasant transit experience are likely to use transit service again, while customers who experience problems with transit cannot use the transit service at a later time (Shaaban \& Khalil, 2013). The impact of poor performance may have greater consequences than the benefits of performance excellence according to Cronin, 2003 in (Mouwen, 2015).

Literature about satisfaction has to be adapted to the context which is to be studied. Customer satisfaction is seen as an answer to completion and fulfillment of needs (Oliver, 1996) in (Brito et al., 2010). The urban transportation system is faced with the challenge of increasing public transport performance in accordance with the expectations or interests of public transport users. Therefore, the problems and challenges of public transportation are very important to pay attention to. Public transportation must be able to provide maximum performance, so as to provide satisfaction for public transport users.

Based on the description above, the analysis satisfaction with the performance of urban public transport is very important to do a research, so that it can find out the strengths and weaknesses of public transport services. Analysis of public transport performance satisfaction is expected to provide a strategy to improve transportation performance oriented towards user satisfaction of urban public transport (Putra et al., 2014).

\section{Methods}

In this study, the data sources needed were primary and secondary data. The variables used in this study are based on minimum service standards of Bekasi City Main Terminal and field observations by seeing and feeling directly as a user. The survey technique in this study was to distribute questionnaires to 90 respondents. This questionnaire consists of 41 questions with the number of answers according to their position. Respondents checked the answers that best match their point of view. The questionnaire in this study uses a facility performance measurement scale and customer satisfaction. The questionnaire is distributed on weekdays, and distributed to public transport users in Bekasi City Main Terminal.

\subsection{Primary Data}

Primary data is a data created by researchers for specific purpose of solving problems being handled by researchers, such as:

1. Questionnaire data

2. Facility 


\subsection{Secondary Data}

Secondary data is a data obtained or collected by researchers from various existing sources.or data obtained indirectly, such as:

1. Bus arrivals

2. Number of Fleets

\subsection{Collection time}

Data Facility data was taken on October 28, 2020 and interview / questionnaire data was taken directly (offline) Monday, December 5, 2020 at 07.00-13.00 while indirectly (online) via google form Monday December 5, 2020 to Monday December 26, 2020.

\subsection{Validity Test}

Test Validity tests are carried out to ascertain how well an instrument used to measure the concept should be measured. According to (Sugiyono, 2014).

\subsection{Reliability Test}

According to Ghozali (in Widagdo \& Rahardjo, 2012) reliability is a measure of the internal consistency of the indicators of a construct which shows the degree to which each indicator indicates a common latent construct / factor

\section{Results and Discussion}

\subsection{General analysis of respondents}

Respondents in this study were users the facilities in Bekasi City Main Terminal with a total of 90 respondents, then from the results of data collection and processing through distributing questionnaires to these respondents, it can be seen from the following tables of respondent characteristics as follows:

Table 1. General Analysis

\begin{tabular}{|c|c|c|}
\hline Category & Frekuensi & Persentation \\
\hline $1 \mathrm{x}$ visit & 28 & $31 \%$ \\
\hline $2 \mathrm{x}$ visit & 23 & $26 \%$ \\
\hline $3 \mathrm{x}$ visit & 18 & $20 \%$ \\
\hline $4 \mathrm{x}$ visit & 2 & $2 \%$ \\
\hline $5 \mathrm{x}$ visit & 19 & $21 \%$ \\
\hline Total & 90 & $100 \%$ \\
\hline
\end{tabular}

\subsection{Gender of Respondents}

In this study respondents were 90 respondents in Bekasi City Main Terminal, with the following characteristics of respondents:

Table 2. Gender

\begin{tabular}{|c|c|c|}
\hline Category & Total & Perssentation \\
\hline Laki-Laki & 39 & $43 \%$ \\
\hline Perempuan & 51 & $57 \%$ \\
\hline
\end{tabular}

\subsection{Age of Respondents}

In this study the respondents were taken a user of Bekasi City Main Terminal with the age of the respondent as follows:

Table 3. Age

\begin{tabular}{|c|c|c|}
\hline Category & Total & Persentation \\
\hline$<20$ Age & 1 & $1 \%$ \\
\hline 20-30 Age & 81 & $90 \%$ \\
\hline 30-40 Age & 7 & $8 \%$ \\
\hline 40-50 Age & 1 & $1 \%$ \\
\hline$>50$ Age & 0 & $0 \%$ \\
\hline Total & 90 & $100 \%$ \\
\hline
\end{tabular}




\subsection{Validity Test}

Table 4. Facility performance validity test

\begin{tabular}{|c|c|c|c|c|}
\hline Variabel & Nilai $R_{\text {finum }}$ & Nilai $\mathrm{R}_{\mathrm{pbs}}$ & Nilax sig. & Keputtuan \\
\hline $\mathrm{X}_{1}$ & \begin{tabular}{|l|}
0,370708 \\
\end{tabular} & 0,207 & 0.000 & Valid \\
\hline $\mathrm{X}_{2}$ & \begin{tabular}{|l|l|}
0,580129 \\
\end{tabular} & \begin{tabular}{|l|}
0,207 \\
\end{tabular} & 0.000 & \begin{tabular}{|l|} 
Valid \\
\end{tabular} \\
\hline $\mathrm{x}_{3}$ & $0,0,563577$ & 0,207 & 0.000 & \begin{tabular}{|l|l} 
Valid \\
\end{tabular} \\
\hline $\mathrm{x}_{4}$ & \begin{tabular}{|l|l|l|} 
\\
\end{tabular} & 0,207 & 0.000 & Valid \\
\hline $\mathrm{X}_{5}$ & \begin{tabular}{|l|l|}
0,702169 \\
\end{tabular} & 0,207 & 0.000 & \begin{tabular}{|l} 
Validi \\
\end{tabular} \\
\hline $\mathrm{X}_{6}$ & \begin{tabular}{|l|l|}
0,686396 \\
\end{tabular} & 0,207 & 0.000 & Valid \\
\hline \begin{tabular}{|l|}
$\mathrm{X}$ \\
\end{tabular} & \begin{tabular}{|l|l|}
0,7193444 \\
\end{tabular} & 0,207 & 0.000 & \begin{tabular}{|l} 
Valid \\
\end{tabular} \\
\hline $\mathrm{X}_{8}$ & \begin{tabular}{|l|}
0,595321 \\
\end{tabular} & 0,207 & 0.000 & \begin{tabular}{|l|l} 
Valid \\
\end{tabular} \\
\hline \begin{tabular}{|l}
$X_{0}$ \\
\end{tabular} & 0,529526 & \begin{tabular}{|l|}
0,207 \\
\end{tabular} & 0.000 & \begin{tabular}{|l|} 
Valid \\
\end{tabular} \\
\hline $\mathrm{X}_{10}$ & \begin{tabular}{|l|l|}
0,734417 \\
\end{tabular} & 0,207 & 0.000 & Valid \\
\hline $\mathrm{X}_{\|}$ & 0 & 0,207 & 0.000 & Valid \\
\hline \begin{tabular}{|l|}
$x_{12}$ \\
\end{tabular} & \begin{tabular}{|l|l|}
0,630195 \\
\end{tabular} & 0,207 & 0.000 & Valid \\
\hline \begin{tabular}{|l|}
$x_{13}$ \\
\end{tabular} & \begin{tabular}{|l|l|l|} 
\\
\end{tabular} & 0,207 & 0.000 & Valid \\
\hline $\mathrm{X}_{14}$ & \begin{tabular}{|l|l|}
0,661045 \\
\end{tabular} & 0,207 & 0.000 & \begin{tabular}{|l} 
Valid \\
\end{tabular} \\
\hline \begin{tabular}{|l|}
$\mathrm{X}_{15}$ \\
\end{tabular} & $0,0,751564$ & 0,207 & 0.000 & Valid \\
\hline
\end{tabular}

\begin{tabular}{|c|c|c|c|c|}
\hline Variabel & Nilai $R_{\text {枟n }}$ & 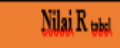 & Niliki sige, & Keputusan \\
\hline$\overline{X_{\mathbb{N}}}$ & 0,764817 & 0,207 & 0.000 & Valid \\
\hline$X_{\#}$ & 0,645417 & 0,207 & 0.000 & Valid \\
\hline$X_{4}$ & 0,699242 & 0,207 & 0.000 & Valid \\
\hline$X_{\|}$ & 0,562968 & 0,207 & 0.000 & Valid \\
\hline
\end{tabular}

\begin{tabular}{|c|c|c|c|c|}
\hline उश्मूरत & 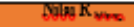 & $\operatorname{sig} K_{\text {nith }}$ & XIIgु & Bepwruseng \\
\hline$x_{16}$ & 0,04356 & 0,217 & 0.0001 & Vara \\
\hline$X_{15}$ & पहाइएक & 0.याग & (10रार & vana \\
\hline$x_{16}$ & 0,671187 & 0,2 IIT & $0.0 \times 10$ & Vara \\
\hline$x_{11}$ & Q,7ाइाइए & 0.2या & $0.0 \times 10$ & Vara \\
\hline$x_{a}$ & $0,7 \times 1047$ & 0,217 & 0.000 & Vala \\
\hline$x=$ & 0,53535 & 02 पाT & (0.0रा & Tawa \\
\hline$X_{2}$ & $0.6 \times 125$ & (0,2या & 0.000 & vasa \\
\hline$x_{2}$ & Q,, 41925 & 0,217 & (10रारा & vala \\
\hline$X_{\Delta}$ & Q,7गमास & (0,याT & 0.0रा & vala \\
\hline$x_{s}$ & 0353572 & 0,217 & $0.000 \%$ & Vara \\
\hline$X_{x}$ & 0.51921 & 0,2117 & $0.000 \%$ & Vara \\
\hline 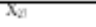 & $0,0.41 \%$ & 0,217 & $0.0 \times 10$ & Vand \\
\hline$X_{\mathrm{s}}$ & 0,552018 & 0,217 & 0.0000 & Vara \\
\hline$x_{3}$ & 0,023 & 0,2 पाT & 0.000 & valad \\
\hline$X_{n}$ & 0,6ा1046 & 0,2117 & 0.000 & Vara \\
\hline$X=$ & 0,77345 & 0,217 & $0.0 \times 10$ & vana \\
\hline$X_{0}$ & 0,661812 & $0,2 \mathrm{IIT}$ & $0.0 \times 10$ & Vand \\
\hline$x_{0}$ & $0,66730 \%$ & 0,2 पा & $0.0 \times 10$ & Vand \\
\hline$X_{1}=$ & 0,001305 & 0,2 पाT & 0.0001 & Vana \\
\hline$X_{6}$ & 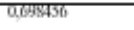 & $0,2 \mathrm{AIT}$ & 0.00010 & Vand \\
\hline$X_{5}$ & Q,75615 & 02217 & $0.0 \times 10$ & vana \\
\hline$x_{n}$ & 0,65045 & 0,217 & 0.0001 & Vara \\
\hline
\end{tabular}

Table 2. Test the validity of customer satisfaction

\begin{tabular}{l|l|l|l|l|}
\hline Variabel & Nilai $R_{\text {kitumg }}$ & Nilai R tabel & Nilai sig. & Keputusan \\
\hline$Y_{1}$ & 0,287277 & 0,207 & 0.000 & Valid \\
\hline$Y_{2}$ & 0,611092 & 0,207 & 0.000 & Valid \\
\hline$Y_{3}$ & 0,387654 & 0,207 & 0.000 & Valid \\
\hline$Y_{4}$ & 0,238767 & 0,207 & 0.000 & Valid \\
\hline$Y_{5}$ & 0,255961 & 0,207 & 0.000 & Valid \\
\hline$Y_{6}$ & 0,505087 & 0,207 & 0.000 & Valid \\
\hline$Y_{7}$ & 0,586218 & 0,207 & 0.000 & Valid \\
\hline$Y_{8}$ & 0,014586 & 0,207 & 0.000 & Valid \\
\hline$Y_{9}$ & 0,034079 & 0,207 & 0.000 & Valid \\
\hline$Y_{10}$ & 0,454563 & 0,207 & 0.000 & Valid \\
\hline$Y_{11}$ & 0,289675 & 0,207 & 0.000 & Valid \\
\hline$Y_{12}$ & 0,284996 & 0,207 & 0.000 & Valid \\
\hline$Y_{13}$ & 0,443779 & 0,207 & 0.000 & Valid \\
\hline
\end{tabular}

\begin{tabular}{|c|c|c|c|c|}
\hline Varlaber & 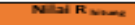 & Nolai fat & Nilais sद्ध & $\overline{\mathrm{Ke}}$ \\
\hline$Y_{1+}$ & 0.496095 & 0.205 & 0.000 & Valic \\
\hline$Y_{1 s}$ & 0.678487 & 0.205 & 0.000 & Valic \\
\hline$Y_{10}$ & 0.000463 & 0.203 & 0.000 & Valic \\
\hline$Y_{17}$ & 0.526119 & 0.207 & 0.000 & Valic \\
\hline$Y_{15}$ & 0.637672 & 0.207 & 0.000 & Valic \\
\hline$Y_{10}$ & 0.750714 & 0.207 & 0.000 & Valia \\
\hline$Y_{3}$ & 0.638179 & 0.207 & 0.000 & Valic \\
\hline$Y_{21}$ & 0.456813 & 0.207 & 0.000 & Valic \\
\hline$Y_{z 2}$ & 0.609985 & 0.203 & 0.000 & Valia \\
\hline$Y_{z z}$ & 0.005769 & 0,205 & 0.000 & Valic \\
\hline$Y_{2 x}$ & 0.671041 & 0.203 & 0.000 & Valic \\
\hline$Y_{25}$ & 0.423246 & 0.207 & 0.000 & Valid \\
\hline$Y_{m}$ & 0.379289 & 0.207 & 0.000 & Valic \\
\hline$Y_{Z T}$ & 0.513163 & 0.205 & 0.000 & Valia \\
\hline$Y=$ & 0.474895 & 0.203 & 0.000 & Valic \\
\hline$Y_{z x}$ & 0,552868 & 0.207 & 0.000 & Valic \\
\hline$Y_{3 x}$ & 0.471049 & 0.203 & 0.000 & Valia \\
\hline$Y_{31}$ & 0.348318 & 0.205 & 0.000 & Valid \\
\hline$Y_{X x}$ & 0.469127 & 0.207 & 0.000 & Valid \\
\hline$Y_{3 x}$ & 0,421734 & 0.203 & 0.000 & Valia \\
\hline$Y_{3}$ & 0.50329 & 0.207 & 0.000 & Valia \\
\hline$Y_{3 s}$ & 0.543703 & 0.205 & 0.000 & Valia \\
\hline
\end{tabular}

\begin{tabular}{|c|c|c|c|c|}
\hline Varlabe! & N & Nitail $\mathrm{F}_{\text {wat }}$ & Nilaisig. & Keputusan \\
\hline$Y_{36}$ & 0,461563 & 0,205 & 0.000 & Valid \\
\hline $\mathrm{Y}_{3}$ & 0,543881 & 0,207 & 0.000 & Valid \\
\hline $\mathrm{Y}_{\mathrm{Fx}}$ & 0,508512 & 0,207 & 0.000 & Valid \\
\hline$Y_{m}$ & 0,354893 & 0,207 & 0.000 & Valid \\
\hline$Y_{40}$ & 0,308596 & 0,207 & 0.000 & Valid \\
\hline$Y_{41}$ & 0,534085 & 0,203 & 0.000 & Valid \\
\hline
\end{tabular}

\subsection{Realibility Test}

Testing is carried out on leveling items that are included in valid category. Reliability testing is done by testing instrument just once. Then analyzed using the Alpha Cronbach method. In this study, the authors performed a reliability test using software SPSS (Statistical Package for the Social Sciences). 
Table 3. Realibility Test

\begin{tabular}{llll}
\hline Variabel & Reliability coefficient & Cronbach Alpha & Result \\
\hline X (performance) & 41 Item question & 0.964 & Reliabel \\
\hline Y (satisfaction) & 41 Item question & 0.912 & Reliabel \\
\hline
\end{tabular}

According to Nunnally (1960) Criteria, the Cronbach Alpha obtained from the reliability test must be greater than 0.60 , so from the description of table above it can be seen that each variable has a Cronbach alpha $>0.60$. This the variable $\mathrm{x}$ (performance) and variable y (satisfaction) can be said to reliable.

\subsection{Analysis of Passenger Responses}

To achieve a good quality service and to attract sympathy from public vehicle passengers at Bekasi City Main Terminal, the authors analyzed the results of the questionnaire from 90 respondents with 41 question items. The results of the questionnaire obtained from an author interview with a passenger public transport in Bekasi City Main Terminal

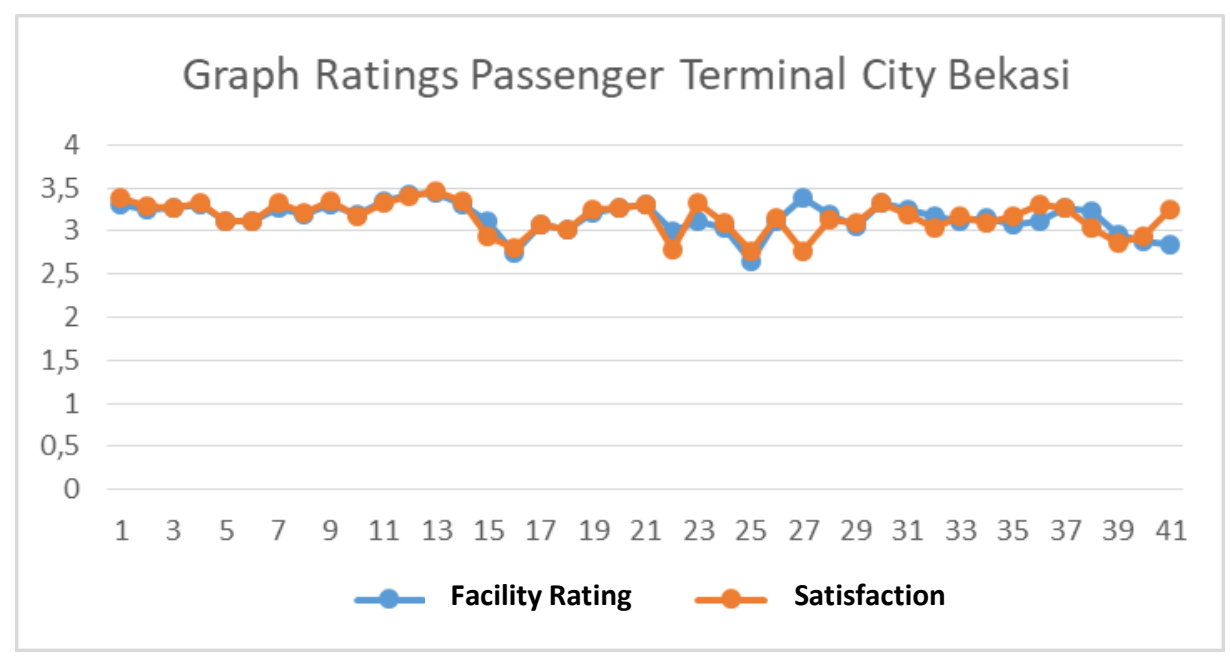

Fig 1. Analysis of Passenger Responses

The average dimension for the assessment of facilities at Bekasi City's Main Terminal is 3.17, so the performance of the facilities provided in each dimension is in the category Good.

The average dimension for the assessment of customer satisfaction at the Bekasi City Main Terminal is 3.26 so that customer satisfaction on each dimension is in the category Satisfied.

\subsection{Cartesian Diagram}

\section{Cartesian chart}

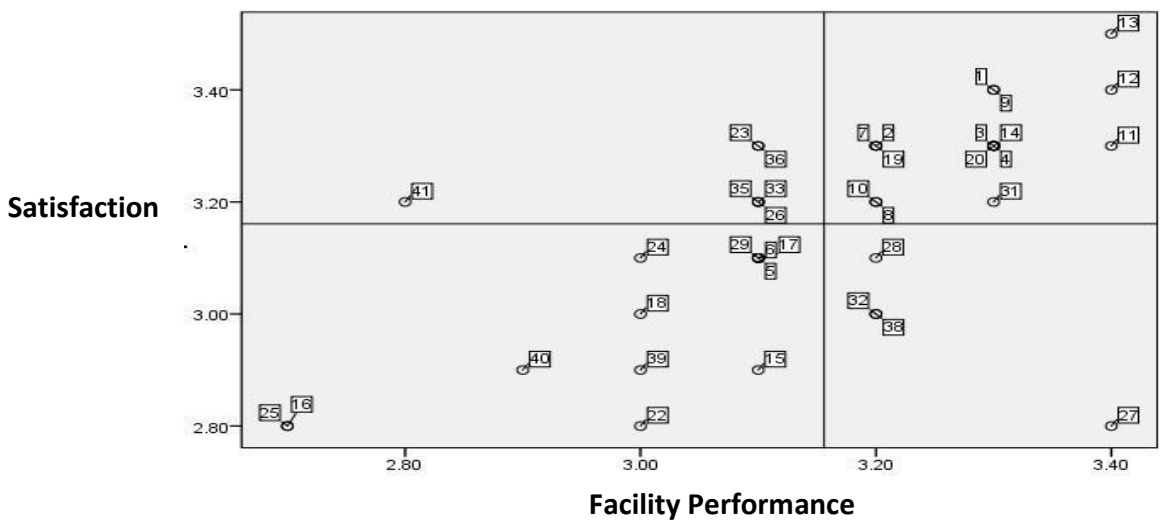

Fig 2. Cartesian Diagram

\section{a. Service factors which are the top priority in handling}

Service factors are the top priority in handling are those in Quadrant A cartesius diagram "Importance Performance analysis", as follows:

a. Availability of facilities for nursing rooms

b. No smoking

c. Availability of Drainage

d. Special access for pedestrians / passengers with special needs

e. Storage of items

f. There is a place for charging batteries 


\section{b. Service factors that must be maintained in terms of performance.}

Service factors must be maintained for performance are service factors that are in Quadrant B cartesius diagram "Importance Performance analysis", are as follows:

a. Information and safety facilities

b. Availability of road safety facilities (signs, markings etc.)

c. Information on the availability of emergency rescue equipment in danger (fire, natural disaster, etc.)

d. Post, facilities and public vehicle eligibility inspectors

e. Availability of security officers in the terminal area

f. Crime prevention equipment such as CCTV at every corner of the terminal

g. Lighting in the terminal area

h. A sticker is available in the form of a complaint telephone number in a strategic place that is easily visible

i. Availability of scheduled arrival and departure times and the amount of public transportation rates in writing

j. Availability of fixed and regular ticket sales counters

k. Availability of terminal administering offices

1. Availability of terminal operational officers who regulate

$\mathrm{m}$. Passenger service facilities in providing information on public transport trips and service complaints

n. Rest area for crew

o. Lighting that functions as a light source in passenger facilities for comfort for passengers

\section{c. Service factor with low priority in handling}

The service factors in the low priority category are in the Quadrant C of the cartesian diagram "Important Performance Analysis", are as follows:

a. Public transportation light repair facilities

b. Meeting point (gathering point) area for passengers to gather together with emergency vehicles

c. Cleanliness in terminal area

d. Public toilet facilities were clean

e. Prayer facilities as a comfortable prayer room

f. Comfortable waiting area

g. Landfills that are differentiated between wet and dry

h. Library

i. There was a bus trip disruption

j. Facilities for passengers with special needs

k. A special lane for passengers who use a wheelchairs

\section{d. Service factor with excessive performance}

Excessive service factors in the Quadrant D cartesius diagram "Important Performance Analysis", are as follows:

a. Area with internet network (Hotspot Area)

b. Service information that is easy to read properly

c. Parking lots for 4-wheel and 2-wheel vehicles around the Bekasi City Main Terminal

d. Road transport information

\section{Conclusions}

Based on results of the research and analysis conducted at the Bekasi City Main Terminal, the following conclusions can be drawn:

1. The average level of passenger satisfaction with services and facilities during the Covid-19 pandemic at the Bekasi City Main Terminal is considered satisfied. Meanwhile, the average performance rating of Bekasi City Main Terminal is considered Good.

2. Customer perceptions of health protocols was applied at the Bekasi City Main Terminal are scored well through interviews and observations of the author with customers in Bekasi City Main Terminal.

3. Suggestions must be considered by the terminal administrator are the existing facilities in Quadrant A, with the following contents:

On the comfort factor, namely:

a. Advice for smoking prohibition

b. Availability of drainage

At the Convenience Factor, namely:

a. Special access for pedestrians / passengers with special needs

b. Storage of items, available for charging batteries

At the Equivalence Factor, namely:

a. Availability of facilities for nursing rooms 


\section{References}

[1] Agarwal, R. (2008). Public Transportation and Customer Satisfaction: The Case of Indian Railways. Global Business Review, 9(2), 257-272.

[2 ] Amir. (2013). Journal of Chemical Information and modeling. In Journal of Chemical Information and Modeling (Vol. 53, Issue 9).

[3 ] Amponsah, C. T., \& Adams, S. (2016). Service quality and customer satisfaction in public transport operations. International Journal of Services and Operations Management, 25(4), 531-549.

[4] Brito, C., Fonseca, F., \& Pinto, S. (2010). Service Quality and Customer Satisfaction in Public Transports. International Journal for Quality Research, 4(2), 125-130.

[5 ] Celik, E., Bilisik, O. N., Erdogan, M., Gumus, A. T., \& Baracli, H. (2013). An integrated novel interval type-2 fuzzy MCDM method to improve customer satisfaction in public transportation for Istanbul. Transportation Research Part E: Logistics and Transportation Review, 58, 28-51.

[6] Eboli, L., \& Mazzulla, G. (2007). Service quality attributes affecting customer satisfaction for bus transit. Journal of Public Transportation, 10(3), 21-34.

[7 ] Friman, M., \& Fellesson, M. (2009). Service Supply and Customer Satisfaction in Public Transportation: The Quality Paradox. Journal of Public Transportation, 12(4), 57-69.

[8 ] Mouwen, A. (2015). Drivers of customer satisfaction with public transport services. Transportation Research Part A: Policy and Practice, 78, 1-20.

[9] Ody Wahyu,M.Zainul arifin, A, W. (2015). Evaluasi kinerja Terminal Induk Kota Bekasi.

[10 ] Putra, A. . A., Yamin, M., Riyanto, B., \& Taufik Mulyono, A. (2014). The Satisfaction Analysis for the Performance of Public Transport Urban Areas. International Refereed Journal of Engineering and Science, 3(8), 38-44.

[11 ] Rizal Fadli. (2020). Corona Virus. https://www.halodoc.com/kesehatan/coronavirus

[12 ] Salam, M. H., Anggraeni, S. K., \& Ummi, N. (2013). Analisis Tingkat Kepuasan Pengguna Jasa Terhadap Kualitas Kinerja Pelayanan Terminal Seruni Kota Cilegon. April.

[13 ] Shaaban, K., \& Khalil, R. F. (2013). Investigating the Customer Satisfaction of the Bus Service in Qatar. Procedia - Social and Behavioral Sciences, 104(1), 865-874.

[14 ] Sugiyono. (2014a). Metode Penelitian Pendidikan pendekatan Kuantitatif, Kualitatif dan R\&D. In METODE PENELITIAN ILMIAH.

[15 ] Sugiyono. (2014b). Populasi dan Sampel. Metode Penelitian Pendidikan Pendekatan Kuantitatif, Kualitatif Dan R\&D.

[16] Widagdo, A. A., \& Rahardjo, S. T. (2012). ANALISIS FAKTOR PEMBENTUK KEPUTUSAN PEMBELIAN PADA PONSEL NOKIA ( Studi Kasus Pada Mahasiswa Fakultas Ekonomika dan Bisnis Undip Semarang ). 1, 1-5. 